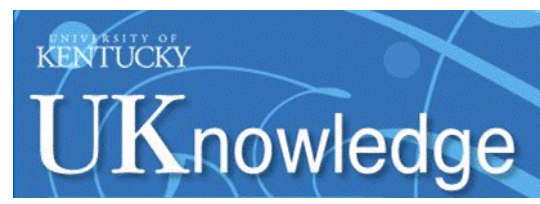

University of Kentucky

UKnowledge

\title{
The $M_{\mathrm{w}}$ 4.2 Perry County, Kentucky, Earthquake of 10 November \\ 2012: Evidence of the Eastern Tennessee Seismic Zone in Southeastern Kentucky
}

\author{
N. Seth Carpenter \\ Kentucky Geological Survey \\ Edward W. Woolery \\ University of Kentucky, ewoolery@uky.edu \\ Zhenming Wang \\ Kentucky Geological Survey
}

Follow this and additional works at: https://uknowledge.uky.edu/ees_facpub

Part of the Earth Sciences Commons, and the Environmental Sciences Commons

Right click to open a feedback form in a new tab to let us know how this document benefits you.

\section{Repository Citation}

Carpenter, N. Seth; Woolery, Edward W.; and Wang, Zhenming, "The $M_{\mathrm{w}} 4.2$ Perry County, Kentucky, Earthquake of 10 November 2012: Evidence of the Eastern Tennessee Seismic Zone in Southeastern Kentucky" (2014). Earth and Environmental Sciences Faculty Publications. 1.

https://uknowledge.uky.edu/ees_facpub/1

This Article is brought to you for free and open access by the Earth and Environmental Sciences at UKnowledge. It has been accepted for inclusion in Earth and Environmental Sciences Faculty Publications by an authorized administrator of UKnowledge. For more information, please contact UKnowledge@lsv.uky.edu. 
The $M_{\mathrm{w}}$ 4.2 Perry County, Kentucky, Earthquake of 10 November 2012: Evidence of the Eastern Tennessee Seismic Zone in Southeastern Kentucky

Digital Object Identifier (DOI)

http://dx.doi.org/10.1785/0220130221

Notes/Citation Information

Published in Seismological Research Letters, v. 85, no. 4, p. 931-939.

(C) 2014 by the Seismological Society of America

The copyright holders have granted the permission for posting the article here.

This article is available at UKnowledge: https://uknowledge.uky.edu/ees_facpub/1 


\title{
Seismological Research Letters
}

\author{
This copy is for distribution only by \\ the authors of the article and their institutions \\ in accordance with the Open Access Policy of the \\ Seismological Society of America.
}

For more information see the publications section of the SSA website at www.seismosoc.org

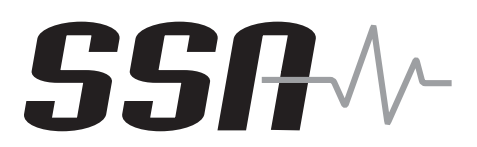

The Seismological Society of America

400 Evelyn Ave., Suite 201

Albany, CA 94706-1375

(510) 525-5474; FAX (510) 525-7204

WwW.seismosoc.org 


\title{
The $M_{\mathrm{w}}$ 4.2 Perry County, Kentucky, Earthquake of 10 November 2012: Evidence of the Eastern Tennessee Seismic Zone in Southeastern Kentucky
}

\author{
by N. Seth Carpenter, Edward W. Woolery, and Zhenming Wang
}

Online Material:Tables of $P$ - and $S$-wave arrivals; earthquake catalog.

\begin{abstract}
The 10 November $2012 M_{\mathrm{w}} 4.2$ Perry County earthquake may represent a continuation of the seismically active Eastern Tennessee seismic zone (ETSZ) farther north than previously recognized into southeastern Kentucky. The mainshock and aftershock data from regional seismic networks and EarthScope's Transportable Array stations allowed highquality determinations of the source parameters. The focal mechanism, depth, and proximity of the mainshock to the New York-Alabama magnetic lineament, a subsurface, crustalscale structure that spatially correlates with central ETSZ seismicity, suggest that this earthquake may share the same type of causal geologic structures as the more-active ETSZ region to the south.
\end{abstract}

\section{INTRODUCTION}

At 12:08 p.m. Eastern Standard Time (17:08 UTC) on 10 November 2012, near the county line between Letcher and Perry Counties in eastern Kentucky, a moment magnitude $\left(M_{\mathrm{w}}\right) 4.2$ (U.S. Geological Survey, 2013) earthquake occurred. Although this earthquake was classified as light, shaking was felt more than $1000 \mathrm{~km}$ away, from the north of Columbus, Ohio, to the south of Atlanta, Georgia, and from west of Henderson, Kentucky, to east of Raleigh, North Carolina (Fig. 1; U.S. Geological Survey, 2013). Moderate-to-strong shaking (modified Mercalli intensity V-VI) was reported within $40 \mathrm{~km}$ of the epicenter in northern Leslie County, Kentucky.
Minor cracks appeared in a basement wall in the Letcher County Courthouse, Whitesburg, Kentucky, $21 \mathrm{~km}$ from the epicenter. In Jenkins, Kentucky, $38 \mathrm{~km}$ from the epicenter, the rate of water flow leaking from the base of a dam increased tenfold after the event (Roach, 2012).

The earthquake occurred beneath the Cumberland Plateau of eastern Kentucky, which had not experienced an earthquake of similar size since 1990. The closest instrumentally recorded seismicity was about $17 \mathrm{~km}$ from the epicenter (Fig. 2). Though sparse in the vicinity of the epicenter, seismicity is continuous, with increasing spatial density from the epicentral region into the central eastern Tennessee seismic zone (ETSZ) to the south (Fig. 2). Seismic monitoring capabilities have been improving in the source region (e.g., Carpenter et al., 2014), and the timely presence of the Transportable Array component of EarthScope's USArray in eastern Kentucky significantly improved the accuracy and completeness of the analysis of this earthquake and it aftershocks.

In this study, we consider the ETSZ to occupy a slightly larger zone than in previous studies (discussed below; Fig. 2): $450 \mathrm{~km}$ long by $120 \mathrm{~km}$ wide, trending largely with and straddling both the New York-Alabama (NY-AL) (King and Zietz, 1978) and the northwestern limit of Iapetan faulting (Wheeler, 1995). This zone includes the region described in Johnston et al. (1985), which has traditionally been used to delineate the ETSZ (e.g., Powell et al., 1994; Wheeler and Frankel, 2000). Our expanded zone contains the bulk of seismicity in the northeast-trending cluster from northeastern Alabama into southeastern Kentucky and all light-class (herein defined as magnitude 3.9 and greater) cataloged earthquakes within and nearby this cluster, including, as we will discuss, the 10 November 2012 Perry County earthquake. 


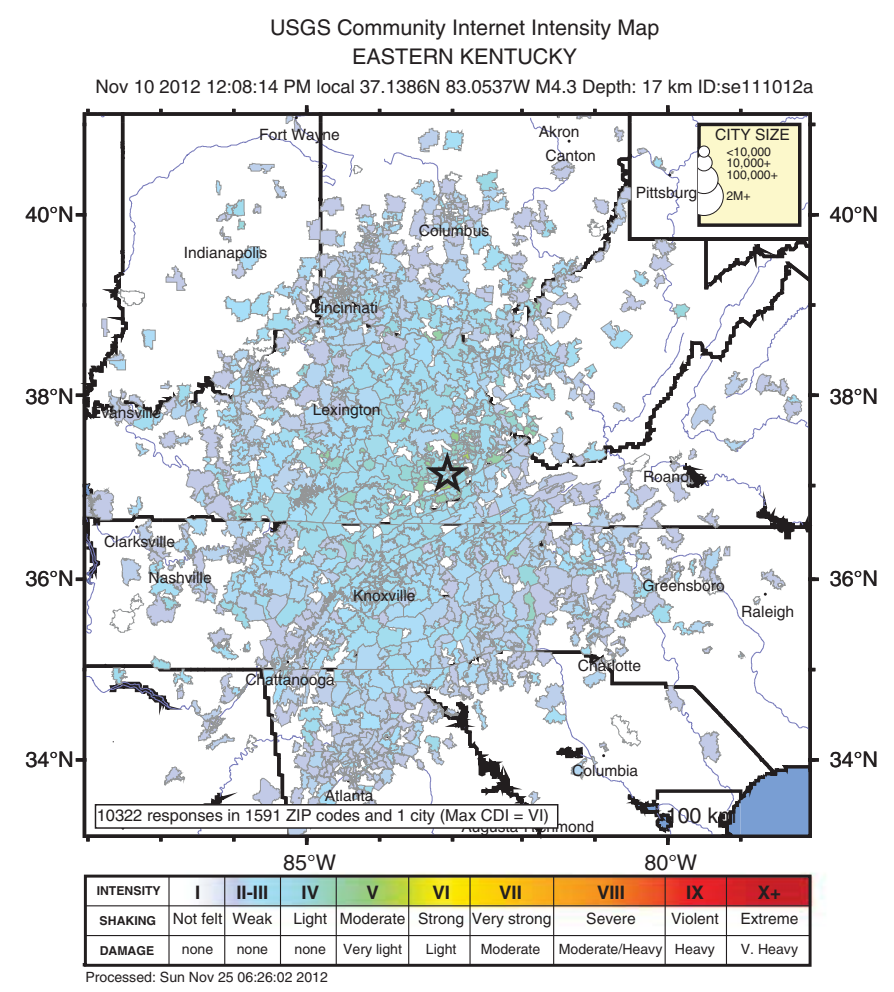

A Figure 1. USGS Community Internet Intensity Map (Courtesy of the USGS; U.S. Geological Survey, 2013) summarizing the experiences of shaking, averaged in each responding zip code, resulting from the 10 November $2012 M_{\mathrm{w}}$ Perry County, Kentucky, earthquake. This map illustrates the broad geographical area over which this earthquake was felt.

\section{SEISMOTECTONIC CONTEXT}

The ETSZ is second only to the New Madrid seismic zone in the central and eastern United States in seismic energy release (Powell et al., 1994; Dunn and Chapman, 2006). It extends into the southeastern corner of Kentucky, which lies within the Cumberland Plateau, an elongated northeast-southwestoriented province that is a transition area between the Interior Plateaus to the west and the folded Appalachian mountains to the east (McFarlan, 1958; Fig. 2). The Pennsylvanian and older Paleozoic clastic and carbonate rocks in the region show significant evidence of tectonism, primarily related to the appurtenant structures that define the Rome trough and Pine Mountain thrust; however, Bollinger et al. (1991) and Dunn and Chapman (2006) indicated most of the earthquake focal depths in the ETSZ lie below the décollment and are not thought to be associated with the surface geology. Johnston et al. (1985) found that between $80 \%$ and $90 \%$ of the seismicity occurred within a $300 \mathrm{~km} \times 50 \mathrm{~km}$ zone of activity that lies between the New York-Alabama (NY-AL) and Clingman (CL) aeromagnetic lineaments that were described by King and Zietz (1978) and Nelson and Zietz (1983), respectively (Fig. 2), and bounded by north latitudes of $36.5^{\circ}$ and $34.3^{\circ}$.

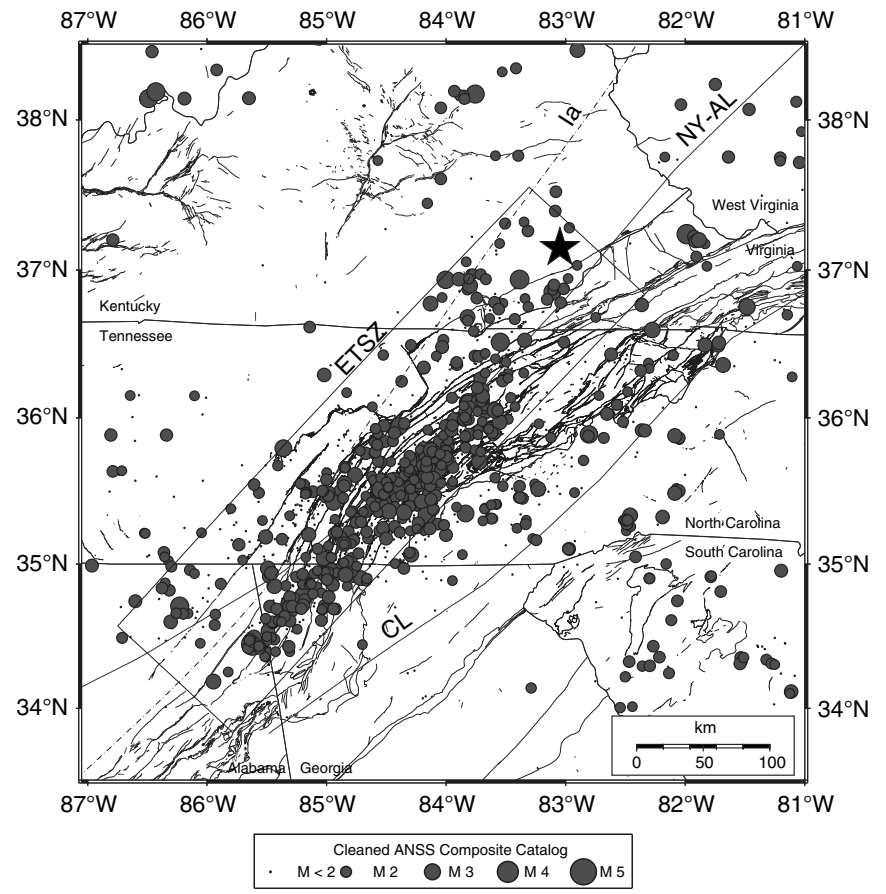

A Figure 2. Seismicity in the eastern Tennessee seismic zone (ETSZ), location of the $2012 M_{\mathrm{w}}$ 4.2 Perry County earthquake (black star), mapped surface faults (thin gray lines), and major aeromagnetic lineaments: the New York-Alabama (NY-AL) and the Clingman (CL), and the northwestern extent of lapetan faulting (la; Wheeler, 1995). Seismicity is an approximately 30-year subset of the Advanced National Seismic System (ANSS) composite cata$\log$, prior to the 2012 earthquake, with mining-related events removed (Street et al., 2002).

The NY-AL lineament extends approximately $1700 \mathrm{~km}$ between northern Alabama and Albany, New York. The CL lineament extends approximately $1000 \mathrm{~km}$ between northeastern Georgia and Maryland. Both lineaments produce longwavelength aeromagnetic signatures that bound an area of low magnetic intensity and varying gradient. Powell et al. (1994) suggested that the seismicity along this anomaly represents an evolving strike-slip fault system; however, neither Johnston et al. (1985) nor Powell et al. (1994) suggested that the NY-AL or CL lineaments are seismogenic, because focal solutions indicated subvertical strike-slip faults with either rightlateral motion along north-south-striking planes or left-lateral motion along east-west-striking planes. Both geometries are consistent with the northeast-southwest-oriented maximum horizontal compressive stress in eastern Tennessee but were considered inconsistent with the northeast-oriented aeromagnetic lineaments. Wheeler (1995) observed that seismicity in the eastern United States decreases from the east to the west (i.e., cratonward; Fig. 2) across the northwestern limit of Iapetan normal faulting. Wheeler (1995) suggests that reactivation of these normal faults, currently under horizontal compression, is responsible for ETSZ seismicity.

Chapman et al. (1997) relocated 474 earthquakes that occurred in the ETSZ between 1977 and 1997 and determined 
the seismic zone consists of a series of northeast-trending, en echelon basement faults that are intersected in at least three locations by east-trending basement faults. They concluded the seismicity results from strike-slip motion along conjugate fault systems with the dominant faults striking $\mathrm{N} 95^{\circ} \mathrm{W}$ and $\mathrm{N} 50^{\circ} \mathrm{E}$. Their relocated focal depths ranged between 1 and $27 \mathrm{~km}$ (average $=16 \mathrm{~km}$ ); however, based on the steeply dipping fault planes, they noted the depth calculations have significant uncertainty. More recently, Dunn and Chapman (2006) relocated approximately 1000 earthquakes using a double-difference algorithm and found the improved hypocenters in the central, most active part of the ETSZ evidenced a weststriking, north-dipping plane, whereas clusters of events near the Tennessee-North Carolina border evidenced a steeply dipping, northwest-striking fault.

The largest instrumentally recorded earthquake in the ETSZ is the 29 April $2003 M_{\mathrm{w}} 4.6$ event near Fort Payne, Alabama (Dunn and Chapman, 2006). The catalog published by Stover and Coffman (1993) also includes the 30 November $1973 M_{\mathrm{w}} 4.0\left(m_{\mathrm{b}} 4.7\right)$ earthquake near Maryville, Tennessee, as well as several other historical events occurring between the mid-nineteenth and twentieth centuries, estimated in the lowto-mid magnitude 4 based on felt area reports. Nuttli (1981) recommended estimating the maximum magnitude of earthquake source zones in the central and eastern United States based on the magnitude of the earthquake with a 1000-year recurrence interval. The mean values for the Bollinger et al. (1989) recurrence relationship suggests a maximum magnitude of $6.4\left(m_{\mathrm{b}}\right)$ for the ETSZ. This estimate is consistent with the paleoseismic observations by Hatcher et al. (2012) of late Pleis- tocene activity near Dandridge, Tennessee, which they suggest likely resulted from two or more $M_{\mathrm{w}} 6.5$ or greater earthquakes.

\section{EVENT ANALYSIS}

\section{Methods}

We used waveform data from several monitoring networks around the epicenter to perform mainshock and aftershock analyses. In addition to the nearby Center for Earthquake Research and Information's (CERI) Southern Appalachian Seismic Network, U.S. National Seismic Network, and Kentucky Seismic and Strong Motion Network stations, the leading edge of the Transportable Array component of EarthScope's USArray (www.earthscope.org/science/observatories//usarray; last accessed March 2013) coincided with the longitude of the mainshock, yielding high-quality observations and allowing excellent geometrical coverage of the source region (Fig. 3). We found aftershocks using a combination of network short-term average to long-term average (STA/LTA) triggering and waveform cross correlation.

We determined single-event locations with the program Hypocenter (Lienert and Havskov, 1995), as implemented in the SEISAN software package (Havskov and Ottemoller, 1999), which employs an adaptively damped, least-squares location algorithm. We used the 1D layered crustal velocity model developed for the ETSZ by Vlahovic et al. (1998) and modified by Chapman et al. (1997) to include a mantle half-space for traveltime calculations (table 1 in Chapman et al., 1997). For all location determinations, we used a distance weighting scheme that linearly downweights the influence of arrivals from 50 to

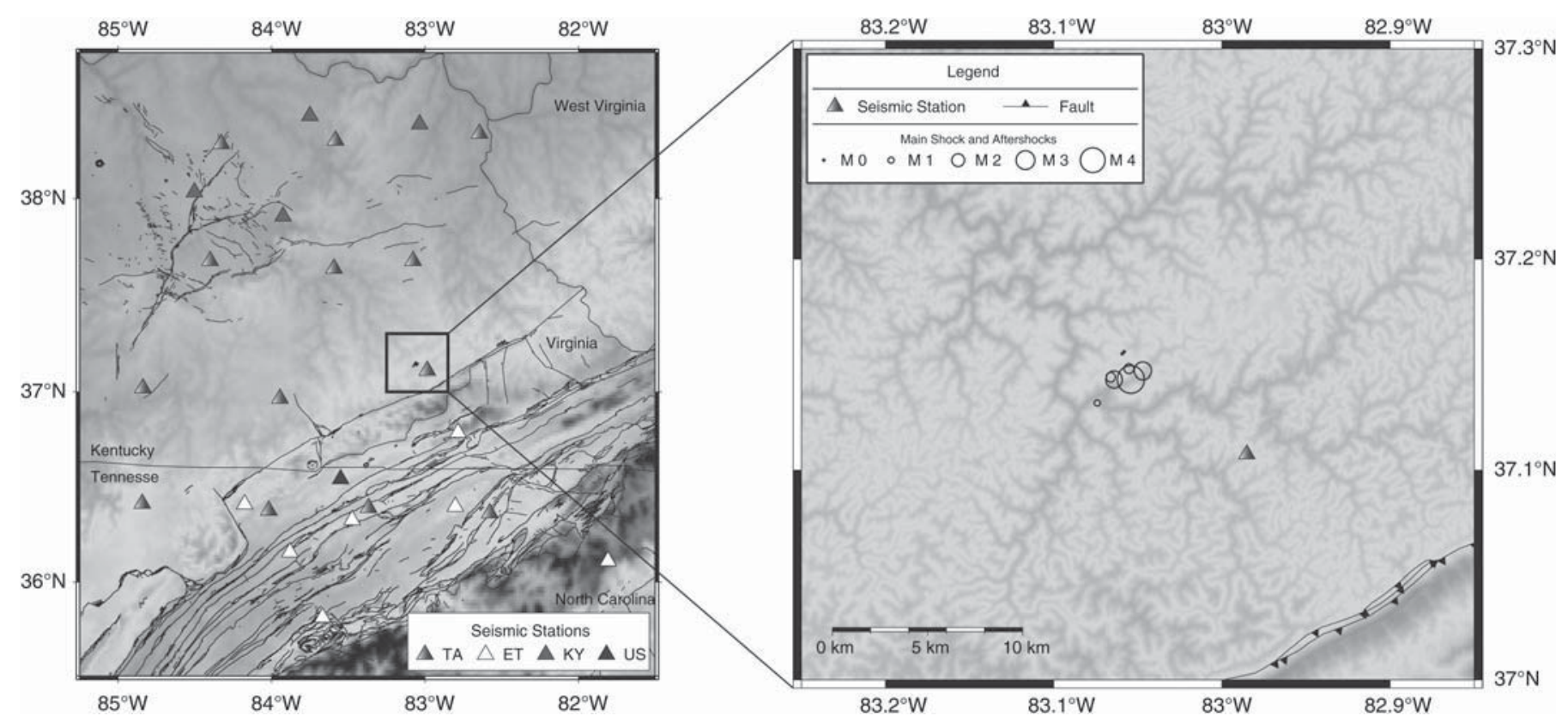

A Figure 3. (Left) Seismic stations used in the analysis of the mainshock and aftershocks and (right) a closer view of the mainshock and aftershock epicenters, the closest seismic station, and mapped faults (barbs are on the hanging wall). Stations are shaded by operating agency: Center for Earthquake Research and Information (ET; white), U.S. Geological Survey (US; black), University of Kentucky (KY; dark gray) stations, and the Transportable Array component of EarthScope's USArray (TA; light gray). 


\begin{tabular}{|c|c|c|c|c|c|c|c|c|c|c|c|c|}
\hline \multicolumn{13}{|c|}{$\begin{array}{c}\text { Table } 1 \\
\text { Perry County Earthquake Mainshock and Aftershock Source Parameters }\end{array}$} \\
\hline $\begin{array}{c}\text { Date } \\
\text { (yyyy/mm/dd) }\end{array}$ & $\begin{array}{c}\text { Time } \\
\text { (hh:mm:ss.s) }\end{array}$ & $\begin{array}{c}\text { Latitude } \\
\left({ }^{\circ} \mathrm{N}\right)\end{array}$ & $\begin{array}{c}\text { Longitude } \\
\left({ }^{\circ} \mathrm{W}\right)\end{array}$ & $\begin{array}{c}\text { Depth } \\
\text { (km) }\end{array}$ & $M_{D}$ & $\boldsymbol{N}_{\text {sta }}$ & $N_{\text {phs }}$ & $\begin{array}{l}\text { Rms } \\
\text { (s) }\end{array}$ & $\begin{array}{l}\text { GAP } \\
\left({ }^{\circ}\right)\end{array}$ & $\begin{array}{l}D_{\min } \\
(\mathbf{k m})\end{array}$ & $\begin{array}{l}\text { ERH } \\
(\mathbf{k m})\end{array}$ & $\begin{array}{l}\text { ERZ } \\
\text { (km) }\end{array}$ \\
\hline $2012 / 11 / 10$ & 17:08:14.1 & 37.143 & 83.054 & 17.3 & 4.3 & 25 & 32 & 0.18 & 112 & 7.3 & 1.6 & 2.4 \\
\hline $2012 / 11 / 10$ & $17: 16: 36.5$ & 37.155 & 83.059 & 15.2 & -0.2 & 6 & 10 & 0.13 & 130 & 8.4 & 5.0 & 3.9 \\
\hline $2012 / 11 / 10$ & $17: 23: 33$ & & & & & & & & & & & \\
\hline $2012 / 11 / 10$ & 17:23:51 & & & & & & & & & & & \\
\hline 2012/11/10 & $17: 39: 55.3$ & 37.145 & 83.066 & 16.0 & 1.4 & 5 & 8 & 0.10 & 121 & 8.3 & 7.0 & 7.4 \\
\hline $2012 / 11 / 10$ & $17: 51: 24.3$ & 37.148 & 83.055 & 16.4 & 1.5 & 18 & 24 & 0.11 & 128 & 7.7 & 2.2 & 1.9 \\
\hline $2012 / 11 / 10$ & 18:37:07.7 & 37.147 & 83.047 & 16.8 & 2.8 & 21 & 23 & 0.13 & 128 & 7.0 & 1.9 & 1.6 \\
\hline $2012 / 11 / 10$ & 19:54:25 & & & & & & & & & & & \\
\hline $2012 / 11 / 10$ & $22: 06: 52.1$ & 37.143 & 83.064 & 16.5 & 2.6 & 20 & 24 & 0.12 & 121 & 8.0 & 1.7 & 1.8 \\
\hline $2012 / 11 / 11$ & 03:13:11.2 & 37.132 & 83.074 & 15.2 & 1.0 & 6 & 9 & 0.09 & 109 & 8.4 & 4.5 & 4.6 \\
\hline $2012 / 11 / 11$ & 06:44:11 & & & & & & & & & & & \\
\hline $2012 / 11 / 11$ & 08:41:01 & & & & & & & & & & & \\
\hline $2012 / 11 / 11$ & 09:13:12 & & & & & & & & & & & \\
\hline $2012 / 11 / 11$ & 10:05:26.7 & 37.156 & 83.058 & 15.0 & -0.4 & 5 & 7 & 0.16 & 131 & 8.4 & 9.1 & 8.0 \\
\hline $2012 / 11 / 11$ & $16: 19: 29$ & & & & & & & & & & & \\
\hline $2012 / 11 / 14$ & 20:19:33 & & & & & & & & & & & \\
\hline
\end{tabular}

$200 \mathrm{~km}$ offsets, with arrivals beyond $200 \mathrm{~km}$ receiving zero weight; at $200 \mathrm{~km}$, travel-time errors due to a flat-earth traveltime calculator (e.g., Snoke and Lahr, 2001) exceed 0.1 s. We obtained precise relative hypocenters for aftershocks using a master-event method (Johnson and Hadley, 1976). We estimated duration magnitudes for all located events using the relationship applied to the southeastern United States in the Southeastern United States Seismic Network Bulletin (Chapman et al., 2002) for all duration measurements. Finally, we determined the focal mechanism for the mainshock using first-motion polarities and phase amplitude ratios with the program FOCMEC (Snoke, 2003).

\section{Mainshock}

Using $32 P$ - and $S$-phase arrivals recorded at 25 stations at offsets from 7 to $179 \mathrm{~km}$ from the epicenter (ㅌ) Table $S 1$ available in the electronic supplement to this article), we determined the mainshock hypocenter to be at $37.143 \pm 0.006^{\circ} \mathrm{N}$, $83.054 \pm 0.014^{\circ} \mathrm{W}$, and $17.3 \pm 2.4 \mathrm{~km}$ below sea level (Fig. 3; Table 1). This location is in agreement with the solution published in the Advanced National Seismic System (ANSS) catalog, which is $1.0 \mathrm{~km}$ to the south and $0.4 \mathrm{~km}$ shallower. Likewise, the duration magnitude we determined, $M_{\mathrm{D}} 4.3 \pm 0.05$, is consistent with the $M_{\mathrm{w}}$ determined by the USGS for this earthquake, which corroborates the duration magnitude scale we employed. We used $33 P$-phase polarities and $P$ - and $S$-phase amplitude ratios $(S V / P, S H / P$, and $S V / S H)$ at four stations to calculate a focal mechanism (Fig. 4; (E) Table S2). Because of the excellent station coverage and the number of polarity observations and amplitude ratios used, the mechanism is very well constrained and shows right-lateral motion on a southwest-striking, steeply dipping plane or left-lateral motion on a southeast-striking, steeply dipping plane. The extremely well-constrained depth proves that this event is of tectonic rather than anthropogenic origin.

\section{Aftershocks}

Using continuous waveform data from stations surrounding the mainshock, we implemented two types of event detection to identify aftershocks. We employed EARTHWORMS's carlstatrig/carlsubtrig network triggering to search for STA/LTA ratio exceedances from multiple stations within a configured time window. We detected five aftershocks with this triggering method, including all but one event with calculated source parameters (discussed below). We also used a $1-8 \mathrm{~Hz}$ bandpass-filtered waveform recorded at the closest station, T52A (7.3 km from the epicenter) from a high-quality aftershock (Fig. 5) to search for events in the continuous data using waveform cross correlation. We used MATLAB to cross correlate the normalized, filtered full waveform from each orthogonal component at this station across 46 days of continuous data: one day prior to the mainshock to search for evidence of foreshocks and the following 45 days. From inspection, we determined that an aftershock is identifiable by an absolute value of the correlation coefficient of at least 0.15 . Using this technique, we discovered 10 additional aftershocks during four days following the mainshock, only one of which $\left(M_{\mathrm{D}}-0.2\right.$ aftershock on 10 November 2012 17:16:36.5; Table 1) was large enough to be recorded by stations farther from the epicenter 


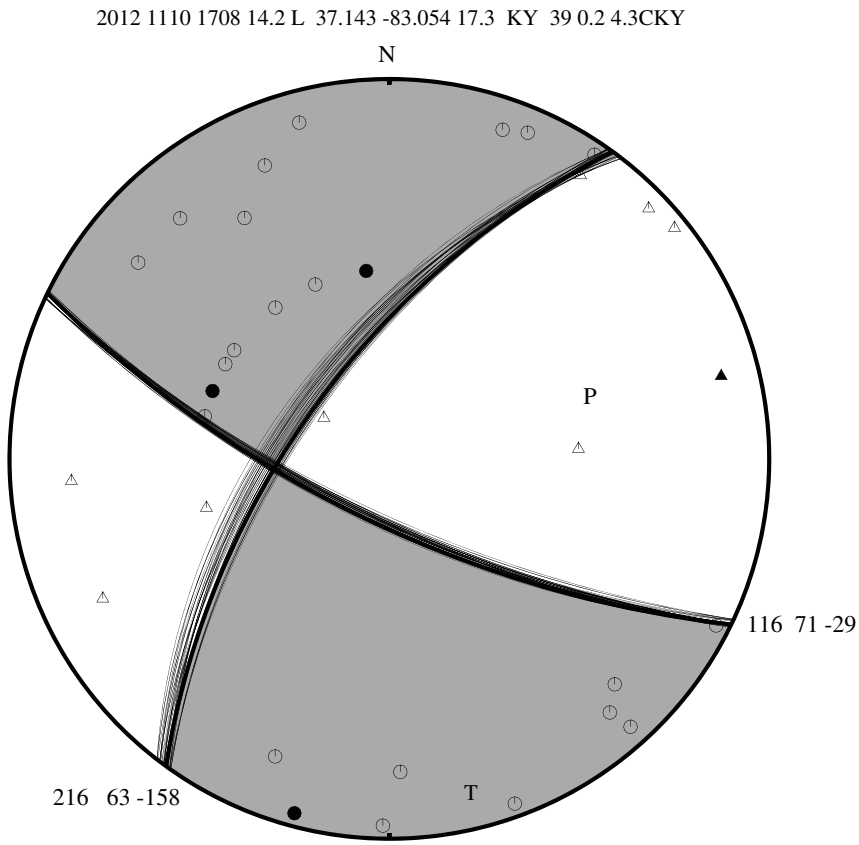

$\Delta$ Figure 4. Focal mechanism (thick lines) of the mainshock determined using first-motion polarities and $P$ - and $S$-phase amplitude ratios. Compressional quadrants are shaded gray, with corresponding first-motion polarity-up observations as circles. Triangles symbolize polarity-down observations. Solid circles and triangles indicate observations of polarities and $P$ - and $S$-phase amplitude ratios. Each nodal plane is labeled with its strike, dip, and rake. Thin, black lines show other solutions that fit the polarity and amplitude-ratio data.

than T52A. We saw no clearly identifiable aftershocks after four days. We estimated the origin times for the events without calculated source parameters by assuming their hypocenters coincide with the mainshock and removing the $P$-phase travel time from the $P$-phase arrival picks, or, if the $P$ phase was not picked, we used the $S$-phase arrival and travel times.

The quality of the lower-magnitude $\left(M_{\mathrm{D}}<1.5\right)$ aftershock hypocenters was limited by the lack of near-source observations. Because of the large location uncertainties (Table 1), and the dearth of events that could be located, there are no clear trends of spatial migration of these events. For the same reasons, we did not attempt to use the aftershocks to infer which nodal plane corresponds with the fault plane of the mainshock.

\section{DISCUSSION}

The Perry County earthquake occurred in a region of reduced seismicity, compared with the heart of the ETSZ (Fig. 2; fig. 1b in Hatcher et al., 2012). However, because it exhibits several characteristics of nearby ETSZ seismicity, the seismogenic structures responsible for the more frequent seismicity to the south may extend farther north into eastern Kentucky than previously recognized. The strikes of the nodal planes we de-
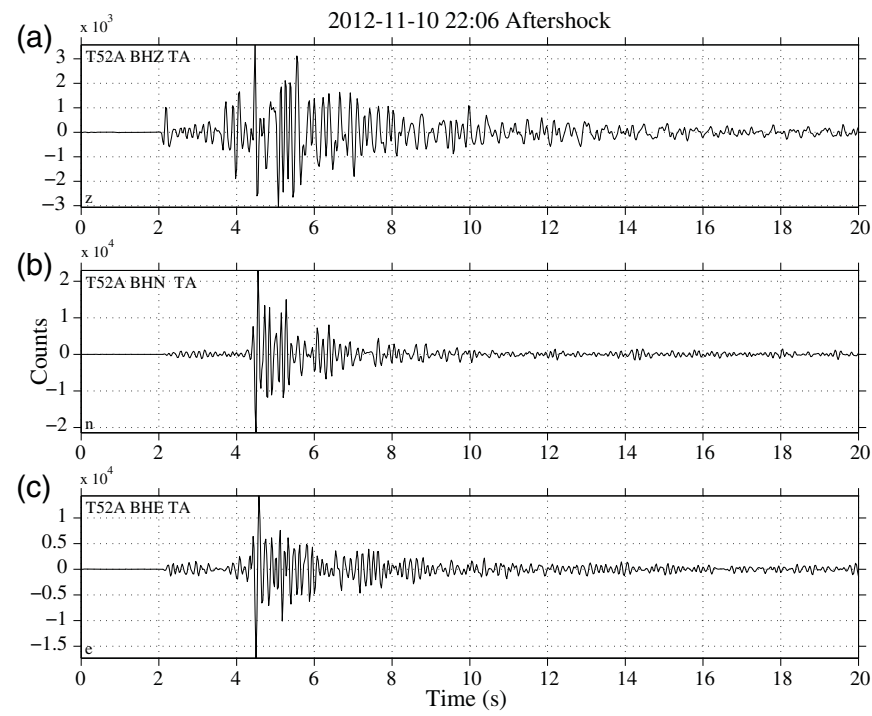

A Figure 5. (a) Vertical-, (b) north-, and (c) east-component waveforms recorded at the closest station, T52A (7.3 km offset), for an aftershock on 10 November at 22:06 (UTC). These waveforms are filtered with a band-pass filter from 1 to $8 \mathrm{~Hz}$ and used to search for small aftershocks via cross-correlation calculations on continuous data recorded at this site.

termined (azimuths $116^{\circ}$ and $216^{\circ}$; Fig. 4) are consistent with other ETSZ events for which focal mechanisms have been determined (Fig 6; Chapman et al., 1997; Hermann et al., 2011). Chapman et al. (1997) found that ETSZ nodal planes fall within two dominant populations: (1) north-south-striking and east-west-striking planes most frequently occur and (2) another less-frequent mode of northeast-southwest and northwest-southeast-striking planes is apparent, which includes the Perry County earthquake (Fig. 6 inset). This suggests that the population of basement faults with northeast-southwest and northwest-southeast-striking planes that Chapman et al. (1997) observed continue into southeastern Kentucky. Regardless of depth (including shallow mechanisms that reside in the overthrust Paleozoic rocks and deeper mechanisms within basement rocks), $P$ axes are consistent with regional stress on both sides of the NY-AL and of the Iapetan-faulting boundary (Wheeler, 1995; Fig. 6).

To make further comparisons with the ETSZ, we use a subset of seismicity from the ANSS catalog for 30 years prior to the Perry County earthquake, after removing events related to mining activity (Street et al., 2002; Figs. 2 and 7). To determine if the density and seismicity-distribution characteristics we observe depend on monitoring network improvements or configurations, we further subset this catalog based on time and magnitude. The regional monitoring network configurations remained relatively unchanged during the 30 years prior to this earthquake, which anticipates little change in detection threshold or seismicity distribution. This was confirmed by finding that the most recent ten years of seismicity maintain the spatial characteristics in the longer, 30-year catalog. In addition, we find that larger-magnitude events (i.e., 


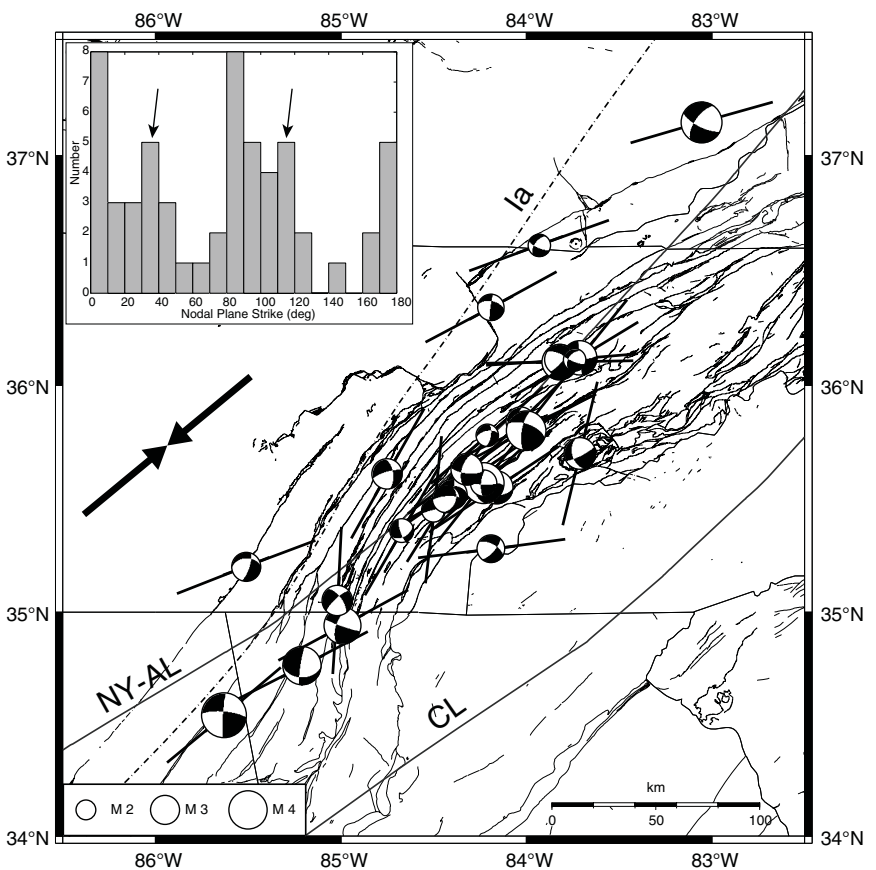

A Figure 6. Focal mechanisms and corresponding $P$-axes determined for the ETSZ (Chapman et al., 1997; Hermann et al., 2011; and this study), within our ETSZ region, with compressional quadrants shaded black. Thick black arrows indicate the orientation of the regional maximum horizontal compressive stress (Heidbach et al., 2008). All other symbols are as in Figure 2. Inset is a histogram of nodal-plane strike frequency (both nodal planes are included for each mechanism). Arrows indicate the bins that contain the Perry County earthquake's nodal planes.

$M_{\mathrm{w}} 2.5$ and greater) have the same spatial and temporal character as the entire catalog. These two observations give us confidence that the characteristics we observe are persistent, and not a function of spatial or temporal variability in monitoring network detection threshold.

From this catalog subset, we find that $66 \%$ of the seismicity lies to the southeast of the NY-AL, in the Ocoee block of basement crust (Johnston et al., 1985; Powell et al., 1994), which is a reduction from Johnston et al. (1985) estimate of $80 \%-90 \%$, and that $89 \%$ occurs southeast of the Iapetan faulting boundary (Wheeler, 1995). By plotting the ETSZ seismicity in cross section and map view (Fig. 7), we observe subzones that can be characterized by variations in spatial density, mean focal depth, and epicentral position with respect to the NY-AL. We determine that the subzones' mean depths are statistically distinct at the $95 \%$ confidence level, and we summarize the depth statistics for each subzone in Table 2. Earthquakes occur predominantly southeast of the NY-AL in the three southwestern subzones (labeled 1 through 3 in Fig. 7). North of approximately $36.2^{\circ} \mathrm{N}$, in subzone 4 , however, the bulk of the seismicity occurs northwest of the NY-AL, presumably in Grenville basement, including the Perry County earthquake. A simple linear regression of focal depth versus distance along this profile, for events of magnitude 3.5 and greater (excluding the Perry County earthquake, but with a sufficient number of events to determine a reliable regression), the depths increase by approximately $33 \mathrm{~m} / \mathrm{km}$. Although the Perry County earthquake is deeper than the mean depths of this seismicity subset and in subzone 4 (Table 2), its focal depth is consistent with the depth predicted by our depth-distance regression, and it falls within the range of depths in the ETSZ overall and in this subzone (Fig. 7).

In addition, we observe the spatial density and temporal frequency of ETSZ seismicity decrease north of $36.2^{\circ} \mathrm{N}$ (Fig. 7; compare to fig. $1 \mathrm{~b}$ in Hatcher et al., 2012). North of this latitude, earthquakes most commonly occur northwest of the NY-AL and larger earthquakes are not necessarily proximal to dense clusters of smaller ones. This same characteristic continues as far north as the Perry County earthquake. We also observe that, although the NY-AL forms the northwestern boundary for most ETSZ earthquakes, larger earthquakes do not show a clear affinity for either terrane that it separates (Grenville basement to the northwest and the Ocoee block to the southeast [Johnston et al., 1985], distinguished by differing magnetic anomaly characteristics), as approximately half of the larger events occur on either side (Fig. 8). Notably, all but one light-class (typically defined as magnitude $4-4.9$, but we include $M_{\mathrm{w}} 3.9$ to account for uncertainties in magnitude estimates) earthquake occurred southeast of the cratonward Iapetan-faulting boundary, supporting the suggestion by Wheeler (1995) that reactivated Iapetan normal faults are responsible for the largest historical earthquakes in the ETSZ.

Finally, we note the Perry County earthquake is the largest earthquake recorded in more than 50 years in the Appalachians of Kentucky. Although earthquakes occur less frequently in southeastern Kentucky than to the south in the central ETSZ, this earthquake is the fourth known event of magnitude 3.9 or greater to occur in this part of Kentucky (Fig. 8; () Table S3). Including two in northern Alabama, one in northwestern Georgia, eight in Tennessee, and three others in southeastern Kentucky, the Perry County earthquake is the fifteenth light-class historical earthquake in the ETSZ (from $33.8^{\circ} \mathrm{N}$ to $37.5^{\circ} \mathrm{N}$ and from $86.8^{\circ} \mathrm{W}$ to $82.4^{\circ} \mathrm{W}$ ). This implies that more than one-quarter of these light-class earthquakes have occurred in southeastern Kentucky, and this is reason enough to consider southeastern Kentucky to be in the ETSZ.

\section{SUMMARY}

The 2012 Perry County earthquake, which we suggest indicates a new northeastern extent of the ETSZ, is the largest earthquake recorded in more than 50 years in the Appalachians of Kentucky. We found the nodal planes of this earthquake's focal mechanism are consistent with one of two dominant populations of ETSZ nodal planes (northeast-southwest and southeast-northwest), as determined by Chapman et al. (1997). In addition, the depth of this earthquake falls within the range observed for the ETSZ and is consistent with the depth predicted by regressing along-axis focal depths versus distance through the ETSZ for larger earthquakes (magnitude 3.5 

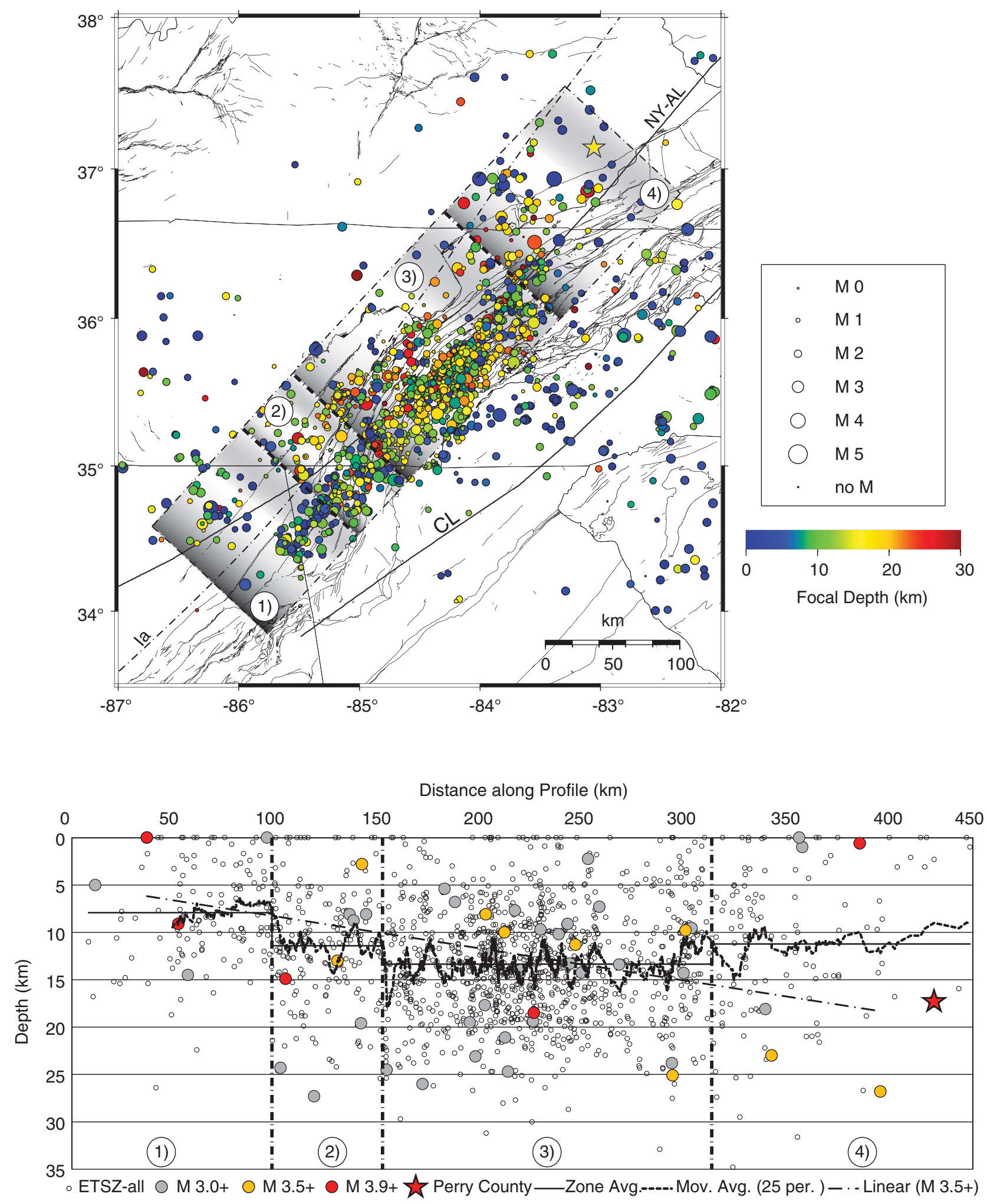

A Figure 7. Seismicity in map view (colored by depth) and in a northeast-southwest cross section (colored by magnitude; $5 \times$ verticalexaggeration) from an approximately 30 -year subset of the ANSS composite catalog, prior to the 2012 earthquake, with mining-related events removed (see Fig. 2). The 10 November 2012 hypocenter is plotted as a star. Hypocenters within the shaded-box region on the map $(450 \mathrm{~km}$ by $120 \mathrm{~km}$ ) are projected onto the cross section. We subdivided the ETSZ into four subzones, delineated by lines (dotted-dashed) on the map and the cross section, and labeled with corresponding numbers 1 through 4 . Three lines are fit to the depthversus-distance data in cross section: dotted-dashed line is the best-fit linear relationship for M 3.5+ earthquakes; the dashed line is a moving average calculated from sets of 25 adjacent points; solid line is the mean depth in each zone. All other symbols are as in Figure 2. 


\begin{tabular}{|ccccc|}
\hline \multicolumn{5}{|c|}{ Table 2 } \\
\hline ETSZ Subzone Focal Depth Statistics \\
\hline 1 & $\boldsymbol{L}(\mathbf{k m})$ & $\boldsymbol{N}$ & Avg $\boldsymbol{Z}$ (km) & STD (km) \\
2 & 100 & 126 & 7.9 & 5.2 \\
3 & 55 & 181 & 11.4 & 6.1 \\
4 & 165 & 1055 & 13.4 & 5.9 \\
\hline L, Along-profile length of subzone; $N$, number of earthquakes \\
in the subzone; Avg $Z$, the mean depth of earthquakes in the \\
subzone; and STD, the subzone sample standard deviation of \\
the depths. \\
\hline
\end{tabular}

and greater). Finally, because the seismicity characteristics (less frequent and sparser) in the vicinity of the epicenter match those seen in the ETSZ north of $36.2^{\circ} \mathrm{N}$ (subzone 4 in Fig. 7), we suggest that this earthquake is evidence that the ETSZ continues into southeastern Kentucky. If the Perry County earthquake is considered to indicate a northeastern extension of the ETSZ, then more than one-quarter of light-class (magnitude

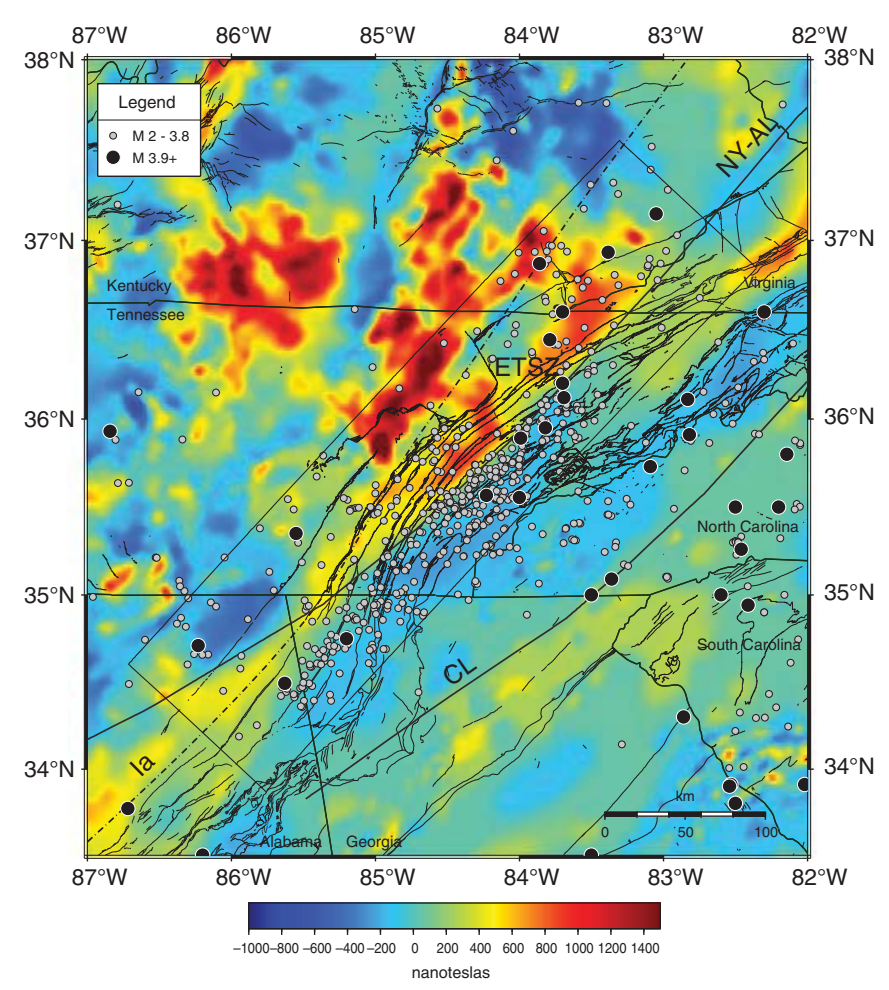

A Figure 8. Magnitude 2.0 and greater seismicity in the ETSZ and aeromagnetic anomalies. Small gray dots are epicenters of magnitude 2-3.8 earthquakes from the cleaned ANSS catalog (Figs. 2 and 7). Larger black dots are light-class historical epicenters of magnitude 3.9 and greater from the Central Eastern United States-Seismic Source Characterization (CEUS-SSC) (Coppersmith et al., 2012), Stover and Coffman (1993), and ANSS (cleaned) catalogs. All other symbols are as in Figure 2.
3.9 and greater) ETSZ earthquakes have occurred in southeastern Kentucky. $\mathbf{<}$

\section{ACKNOWLEDGMENTS}

We wish to thank Martin Chapman and an anonymous reviewer whose suggestions greatly improved this paper. Also, we want to thank Mitch Withers at Center for Earthquake Research and Information (CERI) for supplying us with waveform data and Michael Thorne for his code SACLAB to input Seismic Analysis Code (SAC) data into MATLAB. We also wish to acknowledge the Incorporated Research Institutions for Seismology (IRIS) Data Management Center for their continued services to the seismological community by archiving and serving seismic data. From IRIS, we gathered and used data from the ET, TA, and US seismic networks. All maps were drawn with Generic Mapping Tools (Wessel and Smith, 1998).

\section{REFERENCES}

Bollinger, G. A., F. C. Davison, M. S. Sibol, and J. B. Birch (1989). Magnitude recurrence relations for the southeastern United States and its subdivisions, J. Geophys. Res. 94, 2857-2873.

Bollinger, G. A., A. C. Johnston, P. Talwani, L. T. Long, K. M. Shedlock, M. S. Sibol, and M. C. Chapman (1991). Seismicity of the southeastern United States; 1698 to 1986, Neotectonics N. Am. 1, 291-308.

Carpenter, N. S., Z. Wang, and E. Woolery (2014). Increasing seismic monitoring in the South-Central Appalachians by the Kentucky seismic and strong-motion network, Geol. Soc. Am. Abstracts with Programs, 46, no. 3, Abstract Number 3-9.

Chapman, M. C., E. C. Mathena, and J. A. Snoke (2002). Southeastern United States Seismic Network Bulletin, Number 36, www.geol.vt .edu/outreach/vtso/anonftp/catalog/bul36.pdf (last accessed 8 March 2013).

Chapman, M. C., C. A. Powell, G. Vlahovic, and M. S. Sibol (1997). A statistical analysis of earthquake focal mechanisms and epicenter locations in the eastern Tennessee seismic zone, Bull. Seismol. Soc. Am. 87, 1522-1536.

Coppersmith, K. J., L. A. Salomone, C. W. Fuller, L. L. Glaser, K. L. Hanson, R. D. Hartleb, W. R. Lettis, S. C. Lindvall, S. M. McDuffie, R. K. McGuire, G. L. Stirewalt, G. R. Toro, R. R. Youngs, D. L. Slayter, S. B. Bozkurt, R. J. Cumbest, V. M. Falero, R. C. Perman, A. M. Shumway, F. H. Syms, and M. P. Tuttle (2012). Central and Eastern United States (CEUS) Seismic Source Characterization (SSC) for Nuclear Facilities Project. No. DOE/NE-0140, Electric Power Research Institute (EPRI).

Dunn, M. M., and M. C. Chapman (2006). Fault orientation in the eastern Tennessee seismic zone: A study using the double-difference earthquake location algorithm, Seismol. Res. Lett. 77, 494-504.

Hatcher, R. D., Jr., J. D. Vaughn, and S. F. Obermeier (2012). Large earthquake paleoseismology in the east Tennessee seismic zone: Results of an 18-month pilot study, in Recent Advances in North American Paleoseismology and Neotectonics East of the Rockies, Special Paper 493, R. T. Cox, M. P. Tuttle, O. S. Boyd, and J. Locat (Editors), Geol. Soc. Am., Boulder, Colorado, 111-142, doi: 10.1130/ 2012.2493(06).

Havskov, J., and L. Ottemoller (1999). SeisAn earthquake analysis software, Seismol. Res. Lett. 70, 532-534.

Heidbach, O., M. Tingay, A. Barth, J. Reinecker, D. Kurfeß, and B. Müller (2008). The World Stress Map database release, doi: 10.1594/GFZ.WSM.Rel2008. 
Hermann, R. B., H. Benz, and C. J. Ammon (2011). Monitoring the earthquake process in North America, Bull. Seismol. Soc. Am. 101, 2809-2825.

Johnson, C. E., and D. M. Hadley (1976). Tectonic implications of the Brawley earthquake swarm, Imperial Valley, California, January 1975, Bull. Seismol. Soc. Am. 66, 1133-1144.

Johnston, A. C., D. J. Reinbold, and S. I. Brewer (1985). Seismotectonics of the southern Appalachians, Bull. Seismol. Soc. Am. 75, 291-312.

King, E. R., and I. Zietz (1978). The New York-Alabama lineament: Geophysical evidence for a major crustal break in the basement beneath the Appalachian basin, Geology 6, 312-318.

Lienert, B. R. E., and J. Havskov (1995). A computer program for locating earthquakes both locally and globally, Seismol. Res. Lett. 66, 26-36.

McFarlan, A. C. (1958). Behind the Scenes in Kentucky. Kentucky Geological Survey, University of Kentucky Press, Lexington, Kentucky, $144 \mathrm{pp}$.

Nelson, A. E., and I. Zietz (1983). The Clingman lineament, other aeromagnetic features, and major lithotectonic units in part of the southern Appalachian mountains, Southeastern Geol. 24, no. 3, 147-157.

Nuttli, O. W. (1981). Evaluation of past studies and identification of needed studies of effects of major earthquakes occurring in the New Madrid fault zone, U.S. FEMA Agency VII, Kansas City, Missouri, 28 pp, as cited in Estimation of earthquake effects associated with large earthquakes in the New Madrid seismic zone, M. G. Hopper (Editor), 1985; U.S. Geol. Survey Open-File Report 85457, 186 pp.

Powell, C. A., G. A. Bollinger, M. C. Chapman, M. S. Sibol, A. C. Johnston, and R. L. Wheeler (1994). A seismotectonic model for the 300kilometer-long eastern Tennessee seismic zone, Science 264, 686-688.

Roach, K. (2012). Dam in Jenkins Inspected After Earthquake, www.wkyt .com/wymt/home/headlines/Dam-in-Jenkins-inspected-after-earthquake179370221.html (last accessed 13 June 2013).

Snoke, J. A. (2003). FOCMEC: FOcal MEChanism determinations, in International Handbook of Earthquake and Engineering Seismology, W. H. K. Lee, H. Kanamori, P. C. Jennings, and C. Kisslinger (Editors), chapter 85.12, Academic Press, San Diego, California.

Snoke, J. A., and J. C. Lahr (2001). Locating earthquakes: At what distance can the earth no longer be treated as flat? Seismol. Res. Lett. 72, 538-541.
Stover, C. W., and J. L. Coffman (1993). Seismicity of the United States, 1568-1989 (revised), U.S. Geol. Surv. Profess. Pap. 1527, 418 pp.

Street, R., G. A. Bollinger, and E. Woolery (2002). Blasting and other mining-related activities in Kentucky: A source of earthquake misidentification, Seismol. Res. Lett. 73, 739-750.

U.S. Geological Survey (2013). earthquake.usgs.gov/earthquakes/dyfi/ events/us/c000dqhx/us/index.html (last accessed 13 June 2013).

Vlahovic, G., C. A. Powell, M. C. Chapman, and M. S. Sibol (1998). Joint hypocenter-velocity inversion for the eastern Tennessee seismic zone, J. Geophys. Res. 103, 4879-4896.

Wessel, P., and W. H. F. Smith (1998). New, improved version of the Generic Mapping Tools released, Eos Trans. $A G U$ 79, 579.

Wheeler, R. L. (1995). Earthquakes and the Cratonward limit of Iapetan faulting in eastern North America, Geology 23, 105-108.

Wheeler, R. L., and A. Frankel (2000). Geology in the 1996 USGS seismic-hazard maps, central and eastern United States, Seismol. Res. Lett. 71, 273-282.

$$
\begin{array}{r}
\text { N. Seth Carpenterl } \\
\text { Zhenming Wang } \\
\text { Kentucky Geological Survey } \\
\text { University of Kentucky } \\
504 \text { Rose Street, 228 MMRB } \\
\text { seth.carpenter@uky.edu } \\
\text { zmwang@uky.edu } \\
\\
\text { Edward W. Woolery } \\
\text { Department of Earth and Environmental Sciences } \\
\text { University of Kentucky } \\
\text { 201 Slone Research Building } \\
\text { Lexington, Kentucky 40506 U.S.A. } \\
\text { woolery@uky.edu }
\end{array}
$$

\footnotetext{
${ }^{1}$ Also at Dept. of Earth and Environmental Sciences, University of Kentucky, 201 Slone Research Bldg, Lexington, Kentucky 40506 U.S.A.
} 